\title{
Estimation of Nutrient Loads With the Use of Mass-balance and Modelling Approaches on the Wełna River Catchment Example (Central Poland)
}

Damian Bojanowski ( $\sim$ bojanows@agh.edu.pl )

AGH University of Science and Technology

\section{Paulina Orlińska-Woźniak}

Institute of Meteorology and Water Management

\section{Pawet Wilk}

Institute of Meteorology and Water Management

\section{Ewa Szalińska}

AGH University of Science and Technology

\section{Research Article}

Keywords: nutrients, mass-balance method, modelling, Macromodel DNS/SWAT

Posted Date: January 11th, 2022

DOI: https://doi.org/10.21203/rs.3.rs-1224753/v1

License: @ (i) This work is licensed under a Creative Commons Attribution 4.0 International License. Read Full License 


\section{Abstract}

Nitrogen and phosphorus budgeting is considered to be a useful tool for policy makers and stakeholders when dealing with nutrient contamination issues. Although a variety of budgeting approaches have been employed in countries affected by this problem, the direct comparison of possible options for the same area is quite limited. The current study offers a detailed insight into the estimations of nutrient loads and their distribution between different sources for a middle-sized agricultural catchment, with the use of two approaches: mass balance method and SWAT modelling. As a result of their comparison, both methods revealed similar contributions of analysed nutrient sources, although the absolute loads were heterogeneous, which stems from drawbacks related to the quality of the monitoring data, the performance of the model and omission of some catchment processes. However, in light of the performed comparison, we suggest a hybrid solution, combining the best features of both approaches.

\section{Introduction}

Nitrogen and phosphorus are two key nutrients in aquatic and soil environments, and play an important but somewhat contradicting role in the sustainable development of global and local ecosystems. They are essential for growing crops and maintaining food security, although in many catchments may lead to nutrient overloading as a result of agricultural and industrial activities. As a consequence, the phenomenon of eutrophication is permanently observed, including majority of surface water bodies, and its intensity and extent is growing at an almost pandemic scale, therefore the term "new wave of eutrophication" is currently being used ${ }^{[2]}$. Consequently, effective nutrient management is one of the main challenges in many countries' development agendas. This issue is also promoted and fostered by many international initiatives and organisations, e.g., the United Nations' "The nutrient challenge" or HELCOM's "Nutrient reduction scheme". To address this challenge, nutrient budgeting, which relies on the estimation of inputs and outputs in a given system, is commonly used to provide a useful tool for policy makers and stakeholders. Despite their long history, nutrient budgets still pose many problems, related mainly to the insufficient availability of monitoring or anthropogenic activity data in a given scale $\mathrm{e}^{[3]}$. Although at the same time they have stimulated the development of many complex and advanced modelling tools ${ }^{[4]}$.

In Europe, where approx. $39 \%$ of the total area is used for agricultural production ${ }^{[5]}$ the monitoring of, i.a., nutrient pollution in riverine systems is conducted, in line with the requirements of the European Water Framework Directive (EU WFD). As for the Baltic Sea catchment, the Commission for the Protection of the Marine Environment of the Baltic Sea Area (HELCOM) has obliged all countries that contribute to its pollution, to balance their nutrient inputs ${ }^{[6]}$. Since HELCOM has given its members great flexibility in choosing a nutrient balancing method, a great variability of approaches can be observed among these countries. For the estimation of riverine nutrient loads, emission from sources, retention and load distribution, the following approaches have been selected: i) calculation methods such as the mass-balance method used in Poland, Finland, Latvia, and Germany); ii) simulation methods with the use of models such as HYPE, SWAT or the EstModel used in Russia, Sweden, Lithuania, and Estonia; iii) mixed approaches used e.g. in Denmark ${ }^{[7]}$.

Despite the fact that nutrient balancing for various catchments using both model and computational approaches is frequently reported in many studies ${ }^{[8][9][10][11]}$, no information is available on the results of a direct comparison between these two approaches for the same area. Moreover, individual sources in the modelling approach are rarely estimated in the separate scenarios. The aim of our study is to respond to the absence of this knowledge by demonstrating for the first time the variation of nutrient loadings from different sources in the very same catchment, using source and load oriented approaches in parallel. In the current study, we have compared two substantially different methods of nutrient balancing in a given catchment area, i.e., mass-balance vs. modelling approach. The mass-balance method (load oriented approach) was based on the estimation of nitrogen and phosphorus inputs from the point and of diffuse sources based on the HELCOM guidelines and adopted by Polish PLC-7 methodology ${ }^{[12]}$ used for reporting nutrient emission in the Baltic Sea Basin area and load inputs to the Baltic Sea. The modelling approach, meanwhile, was based on the Macromodel DNS/SWAT and an advanced multi-stage scenario analysis. This comparison has been performed for the agricultural catchment of the Wełna

Page 2/18 
River of central Poland, constituting one of the right tributaries of the Odra River which discharges to the Baltic Sea through the Szczecin Lagoon.

\section{Methods}

\subsection{Case study area}

The studied catchment $\left(2621 \mathrm{~km}^{2}\right)$ is located in the central-western part of Poland, and constitutes a part of the Oder River basin. The Wełna River $(118 \mathrm{~km})$ discharges to the Warta River near the town of Oborniki, ${ }^{[13]}$ with an average flow rate of 8.1 $\mathrm{m}^{3} \mathrm{~s}^{-1}$ (1980-2019) in this profile ${ }^{[14]}$. The natural conditions in this catchment favour the development of intensive agriculture, which covers almost $72 \%$ of this area $\left(1888 \mathrm{~km}^{2}\right)$ and contributes to the high consumption of mineral fertilizers ${ }^{[15]}$. Forest areas cover another $22 \%$ of this catchment $\left(589 \mathrm{~km}^{2}\right)$, while urbanized ones only $4 \%\left(93 \mathrm{~km}^{2}\right)(\mathrm{Fig} .1)$. The Wełna River catchment is inhabited by approx. 230000 people, of which only approx. $74 \%$ is served by wastewater treatment facilities ${ }^{[16]}$.

\subsection{Input data}

Both the mass-balance method and the modelling method require a similar amount and type of input data (Supplementary Table S1). Basic information on the Wetna River daily flow rates and nutrient concentrations in the closing profile of the catchment (Oborniki) has been obtained from the state monitoring services (Institute of Meteorology and Water Management - National Research Institute - IMGW-PIB ${ }^{[14]}$ and State Environmental Monitoring ${ }^{[17]}$ - SEM) (Supplementary Table S1). They have formed the basis for the estimation of the share of individual sources in the mass-balance method, as well as for the calibration of the Macromodel DNS/SWAT in the modelling method. Other data, such as maps of elevation, river network and soil maps, as well as meteorological data, necessary for the development of an accurate representation of the studied catchment area on the Macromodel DNS/SWAT digital platform, were also obtained from state repositories. Data on the land use comes from the Corine Land Cover ${ }^{[18]}$, while detailed information on nutrient sources has been obtained mostly from the Local Data Bank of statistical information. The utilisation of the collected database has been presented in Fig. 2, and described in the following text. The comparison of the results for nutrient loads from both method was based on the year 2017, which was characterized by the maximum amount of monitoring data for both flows (365 measurements) (IMGW-PIB) and total nitrogen (TN) and total phosphorus (TP) (12 measurements - SEM).

\subsection{Mass-Balance method}

The first method used for the quantification of sources and loads in the studied area was the mass-balance method. It is widely used by the Polish administration authorities responsible for water management ${ }^{[12]}$. This method is based on the assumption that the sum of the nutrient loads in the river's closing profile (based on monitoring data) and its retention in the catchment equals the emission of nutrients in a given time. Such assumption allows the apportioning of the river loads among identified sources and the estimation of their contribution to the total loads, based on known or assumed values of their retention.

\subsubsection{River load calculation}

The total load of nutrients discharged from the catchment was calculated using the daily flow rate and nutrient concentrations in the closing profile of the catchment area (Oborniki, Fig. 1) from the SEM (Supplementary Table S1). The daily river load was calculated using the following equation ${ }^{[6]}$.

$$
L_{\text {river }}=0.0864 \sum_{t=1}^{n=365}\left(Q_{t} \cdot C_{t}\right)_{t}
$$

Page $3 / 18$ 
where: $L_{\text {river }}$ is the annual load $\left[\mathrm{kga}^{-1}\right], n$ is the number of days, $t$ is the consecutive day, $C_{t}$ is the concentration $\left[\mathrm{mg} \mathrm{L}^{-1}\right], Q_{t}$ is the mean daily flow rate $\left[\mathrm{Ls}^{-1}\right]$, and 0.0864 is the unit conversion.

Due to the fact that the flow rate is measured daily and nutrient concentrations only 12 times a year, the linear interpolation method ${ }^{[6]}$ was used to obtain the daily concentration values:

$$
x_{k}=x_{a}+k \cdot \frac{x_{b}-x_{a}}{n+1}
$$

2

where: $x_{k}$ is the interpolated concentration value, $x_{a}$ is the first of the two measured concentration values between which the concentrations are interpolated, $x_{b}$ is the second of the two measured concentration values between which the concentrations are interpolated, $k$ is the consecutive number of missing value and $\mathrm{n}$ is number of missing values.

\subsubsection{Source apportionment}

For the mass-balance method, data on nutrient loads for source apportionment (emission inventory) was collected in order to proceed with further calculations. The calculations were performed for 2017 , due to the availability of river monitoring data and the nutrient sources were divided into 7 categories, based on the HELCOM guidelines ${ }^{[6]}$ : municipal (MWS) and industrial (INS) point sources, municipal diffuse sources (SCS), forestry (MFS), agriculture (AGS), natural background (NBS) and atmospheric deposition (ATS). The category of "other sources" (UKS) was taken into account, in order to include possible unknown sources of nutrients in load apportionment, and to cover eventual differences between calculated river load and inventoried emission.

The MSW loads were calculated on the basis of the number of inhabitants served by the wastewater treatment plants (WWTPs) ${ }^{[16]}$. In the Wełna River catchment, 151771 inhabitants were served by the 12 WWTPs covered by the National Wastewater Treatment Program (NWTP) ${ }^{[19]}$, which provides information on the total discharge volume from each facility. For 5 of these plants, information on influent/effluent nutrient concentrations was also available, allowing the direct calculation of discharged loads. For the remaining facilities (7), the loads were calculated on the basis of the mean influent concentration information, available for the WWTPs covered by the NWTP $\left(80 \mathrm{mgL}^{-1}\right.$ and $12 \mathrm{mgL}^{-1}$ for TN and TP, respectively), and approximated nutrient reduction level in non-biological WWTPs. This reduction level, based on data from the NWTP, was set at $65 \%$ for TN and $35 \%$ for TP ${ }^{[19]}$. Another 19350 inhabitants of this catchment were connected to the small WWTPs, not included in the NWTP. This part of the MSW load was calculated using the mean daily wastewater outflow ( $0.12 \mathrm{~m}^{3} \mathrm{day}^{-1}$ per person), the same mean nutrient concentrations and reduction levels as presented above. Additionally, the remaining $25 \%$ of the catchment's population (58 000) is not connected to any WWTP and uses septic tanks and other types of individual wastewater treatment systems. The load from this source was expressed as SCS, and calculated using unit loads set on $11 \mathrm{gday}^{-1}$ per person and $1.6 \mathrm{gday}^{-1}$ per person for TN and TP, respectively ${ }^{[12]}$. The industrial nutrient input information (INS) was gathered directly from the Statistics Poland office database ${ }^{[16]}$.

The AGS load was calculated using nitrate and phosphate concentrations in shallow groundwater $(90 \mathrm{~cm}$ below the ground surface), from 22 sampling points located on agricultural areas in the Wetna River catchment ${ }^{[12]}$. Concentrations were recalculated to TN and TP respectively and averaged. Thus, the obtained mean concentrations were $8.25 \mathrm{mgL}^{-1}$ of TN and $1.92 \mathrm{mgL}^{-1}$ of TP. Subsequently, load values were calculated by multiplying these concentrations by the outflow from agricultural areas, calculated as the total catchment outflow corresponding to the catchment part covered by the agricultural use. The calculated loads were multiplied by coefficients reflecting the share of monitored outflow (groundwaters and tile 
drainage) from the agricultural runoff (1.11 for TN and 4.17 for TP) ${ }^{[20]}$. Subsequently, the natural background (NBS) was subtracted from the AGS load.

The load corresponding to NBS was calculated using the total catchment outflow and nutrient concentration values reflecting conditions in undisturbed areas of pre-human activity, set as $0.15 \mathrm{mgL}^{-1}$ and $0.02 \mathrm{mgL}^{-1}$, for TN and TP respectively ${ }^{[12]}$. The MFS load was also calculated in a similar way, using nutrient concentrations set to represent forest catchment as $0.31 \mathrm{mgL}^{-1}$ and $0.038 \mathrm{mgL}^{-1[12]}$ and the outflow calculated as the share of the total catchment area, respective for the catchment part covered by forest. Also in this case, the NBS load has been subtracted. As for the ATS load, data on pollutant deposition into the ground from precipitation was taken from the SEM network ${ }^{[21]}$. This data was based on precipitation and its chemistry measurements taken from 22 monitoring stations covering the entire territory of Poland. The total load from the point and diffuse sources was calculated by adding the loads mentioned above. The eventual difference between the river load (section 2.3.1) and inventoried emission (section 2.3.2) accounted for the other sources (UKS).

\subsubsection{Load apportionment}

The contribution of each source to the calculated river load was calculated based on a simplified equation modified from HELCOM[6]:

$$
L_{\text {river }}=D P+L O D-R P-R D
$$

3

where: $L_{\text {river }}$ is the river load [ $\mathrm{kga}^{-1}$ ], DP is the load from point sources (MWS and INS) [kga ${ }^{-1}$ ], LOD is the load from diffuse sources (SCS, ATS, MFS, AGS, and NBS) $\left[\mathrm{kga}^{-1}\right], \mathrm{RP}$ is the point source retention $\left[\mathrm{kga}^{-1}\right]$ and RD is the diffuse source retention $\left[\mathrm{kga}^{-1}\right]$.

In the adopted mass-balance method, it is assumed that nutrient load from the point sources (DP) is introduced directly into the river bed phase, while load from the diffuse sources (LOD) is discharged into both phases of the catchment, land and river bed ones. In both phases, self-purification processes are taking place, resulting in the reduction of nutrient loads on the way from the source to the catchment closing profile. However, due to the limited amount of data, the self-purification processes in the river have been omitted, therefore the point source retention (RP) equalled $0 \mathrm{kga}^{-1}$. Subsequently, the diffuse source retention (RD) has been estimated on the basis of the difference between each nutrient load of the river ( $\left.\mathrm{L}_{\text {river }}\right)$ and the point sources (LOD). The remaining river load has been then attributed proportionally to the contribution of the particular diffuse sources to the total source apportionment (emission inventory).

\subsection{Modelling method}

The digital platform, the Macromodel DNS with the SWAT module[22][23][24][25][26][27], was used for comparison for the nutrient balancing method described in section 2.3. This advanced tool tracks nitrogen and phosphorus migration paths in a river catchment, taking into account a very extensive input database, similar to one used in the Mass-Balance method (Supplementary Table S1). Natural and anthropogenic processes that affect the transport and transformation of nutrients, are also part of this platform. The SWAT module (version 2012) is a tool which operates in the spatial information system (GIS) and is fully integrated with it. Using the digital elevation model (DEM), the SWAT module divided the entire analyzed Wetna River catchment into a total of 225 sub-catchments of an average area of $11.5 \mathrm{~km}^{2}$. The subsequent use of data on land use (forests, agriculture and urbanized areas) and the types of soils (31 classes) allowed the authors to identify a total of 2824 hydrological response units (HRUs), homogeneous in terms of vegetation, soil and topography ${ }^{[28]}$. Afterwards, a simulation of precipitation, evapotranspiration, surface runoff, primary and underground flows was carried out in accordance with the water balance equation (4), which represents the basis for the quantitative component and the HRU. 


$$
S W_{t}=S W_{0}+\sum_{i=1}^{t}\left(R_{d a y}-Q_{\text {surf }}-E_{a}-W_{\text {seep }}-Q_{g W}\right)
$$

where: $S W_{t}$ is the final soil water content $\left(\mathrm{mm} \mathrm{H}_{2} \mathrm{O}\right), S W_{0}$ is the initial soil water content $\left(\mathrm{mm} \mathrm{H}_{2} \mathrm{O}\right), R_{\text {day }}$ is the amount of precipitation $\left(\mathrm{mm} \mathrm{H}_{2} \mathrm{O}\right), Q_{\text {surf }}$ is amount of surface runoff $\left(\mathrm{mm} \mathrm{H}_{2} \mathrm{O}\right), \mathrm{E}_{\mathrm{a}}$ is the amount of evapotranspiration $\left(\mathrm{mm} \mathrm{H}_{2} \mathrm{O}\right)$, $W_{\text {seep }}$ is the amount of water entering the vadose zone from the soil profile $\left(\mathrm{mm} \mathrm{H}_{2} \mathrm{O}\right), Q_{g w}$ is the amount of return flow ( $\mathrm{mm}$ $\mathrm{H}_{2} \mathrm{O}$ ).

The model directs all runoff flows generated by each HRU through the channel network, thus simulating a catchment. The water balance equation also represents a basis for the simulation, transport and transformation of nutrients required for the quantitative component of the model. This tool models five organic and inorganic $\left(\mathrm{NH}_{4}{ }^{+}\right.$and $\left.\mathrm{NO}_{3}{ }^{-}\right)$forms of nitrogen, six different forms of phosphorus (three organic and three inorganic) in soil ${ }^{[29]}$, as well as organic nitrogen and phosphorus forms associated with plant residues, microbial biomass and soil humus [30][31][32][33]. Further details on the water balance and the equations of the nutrient related process can be found in the SWAT theoretical documentation ${ }^{\text {[34] }}$.

Similarly, as in the case of the mass-balance method, diffuse sources of nutrients from agriculture (AGS), forestry (MFS) or urban areas (URB) in SWAT were simulated in the land phase of the catchment. In the land phase, the model simulates both the infiltration of nutrients into the soil (fertilization, plant biomass, precipitation) and their removal from it (volatilization, denitrification, erosion, surface runoff). Additionally, changes in the distribution of nutrients in the soil (uptake by plants) and the low mobility of phosphorus itself are also taken into account ${ }^{[34][35][36]}$.

Pollutants from municipal and industrial point sources (MWS, INS) are introduced directly into the river bed phase. The exception here is the nutrient load from municipal diffuse sources (SCS) which, reduced as a result of the self-purification processes taking place in the land phase, is also treated in the model as point sources. The SCS nutrient load mainly derives from leaking or illegally emptied septic tanks. For this purpose, septic tanks have been divided into three types: leaky, partially illegally emptied, and sealed septic tanks, legally emptied. The loads from the legally emptied tanks are included in the effluents from WWTPs reported in the catchment. While for the remaining types, their loads are calculated using factors depending on their effectiveness in nutrient removal (15-50\%). The final nutrient load derived from these types of facilities is then calculated, taking into consideration the number of inhabitants using the different types of septic tanks and the average chemical composition of wastewater ${ }^{[16]}$.

The load of nutrients from the atmospheric deposition (ATS) affects both land and river phases due to the presence of two deposition mechanisms in the SWAT module, i.e., wet and dry deposition. The model also allows for the determination of nutrient loads generated as a result of natural processes of nitrogen and phosphorus transformation and transport in the soil, with the omission of all anthropogenic pressure - natural background (NBS).

\subsubsection{Calibration, verification and validation}

The SWAT module for the Wetna River has been calibrated, verified and validated using the SWAT-CUP software ${ }^{[37]}$. For the quantitative component (water circulation in the catchment), the implemented daily flow data (source: IMGW-PIB) for the period of 18 years (2001-2018) came from the water gauge stations on the Wełna River (Pruśce and Kowanówko) and its tributary (the Flinta River-Ryczywół) (Fig. 1). The qualitative component (nitrogen and phosphorus concentration in the catchment) was gathered from the SEM stations localised at the Wełna River (Oborniki and Rogoźno) (Fig. 1) and covered a

period of 13 years (2005-2018). Three statistical measures, coefficient of determination (R2) ${ }^{[38]}$, percent bias (PBIAS) ${ }^{[39]}$, and Kling-Gupta efficiency (KGE) ${ }^{[40]}$, have been used to indicate the Wełna River model performance (Supplementary Table S2 and S3). In terms of the quantitative component, the calibration and verification coefficients R2, KGE and PBIAS classified 
the model performance generally as good and very good for the main river (Wełna), and satisfactory and good for its tributary (Flinta). During the validation procedure, all coefficient values rated the model performance for daily flow simulations as very good. In terms of qualitative components, the model performance for TN simulations can be considered as very good or good, according to the all-applied coefficients. Lower model performance, mostly satisfactory, was observed for TP mainly due to the variability of phosphorus temporal distribution patterns (Supplementary Table S2). The entire process was described in detail in Orlińska-Woźniak et al. ${ }^{[41]}$

\subsubsection{Variant scenarios}

In order to determine the contribution of individual sources to the total load of nutrients in the profile closing the analyzed catchment, a final simulation of the model was used and subjected to calibration, verification and validation procedures, and called the baseline scenario (A0). Subsequent so-called variant scenarios (A1-A5), i.e. model simulations, were developed. In variant scenarios the values of selected parameters were changed in relation to the $\mathbf{A} 0$ scenario. This was used both in the river bed phase for point sources (A1) and for individual diffuse sources (A2-5), thus imitating surface changes for particular types of land use in the land phase of the catchment (Fig. 3).

In the A1 scenario, all parameterized and aggregated point sources (MWS, INS, SCS) for each relevant sub-basin $\left(L_{M S W, I N S, S C S}\right)$, were removed from the model to calculate their contribution to the total nutrient loads in the closing profile of the studied catchment (LA1).

In the next two scenarios (A2 and A3), concerning urban and agricultural land use, their surface areas (5 663 ha and 192917 ha, respectively) were successively replaced by the forest land use. This procedure was based on the assumption that the forest is the primary type of land use for this catchment area ${ }^{[42]}$. In order to completely eliminate the influence of these areas, the nutrient loads from the relevant surface area occupied by forest land use were subtracted, in order to estimate the contribution of forest and agricultural land ( $\mathrm{L}_{\mathrm{URB}}$ and $\mathrm{L}_{\mathrm{AGS}}$, respectively).

The change in land use from urbanized and agricultural areas to forest areas increased their percentage of the catchment area to almost $100 \%$, thus the original image of the catchment area and the nutrient load at its mouth. On this basis, in scenario $A 4$, the nutrient load from forests $L_{M F S}$, which currently occupy only $20 \%$ of the catchment area (A0), flowing to the closing profile, was calculated from the proportion.

The $\mathbf{A} 5$ scenario is the difference between the nutrient load from the $\mathbf{A} 0$ scenario and the sum of the remaining loads from the subsequent variant scenarios (A1-4). In this way, both the natural background (NBS) and atmospheric deposition (ATS) were taken into account.

\section{Results}

For the purposes of the current research, two significantly different methods of source identification and estimation of their contribution to the total nutrient load have been selected. The confrontation of the mass-balance method with the modelling approach revealed clear differences in the total estimates for the closing profile of the analysed catchment (Oborniki) and also in the individual contribution of each source. As for the river load for this profile, used as a basis for the mass-balance method, calculated using data from the SEM and flow measurements, the loads amounted to approx. 3121 ty $^{-1}$ (tonnes per year) and $65 \mathrm{ty}^{-1}$ for TN and TP, respectively. While the modelling results for the baseline scenario (A0) demonstrated values lower by approx. $935 \mathrm{ty}^{-1}$ and $13.4 \mathrm{ty}^{-1}$ for TN and TP, respectively (Table 1).

The contribution of particular nutrient sources has been determined depending on the capabilities of both methods and limitations of the available data. Nutrient loads discharged from the different types of wastewater treatment facilities used by the inhabitants of the catchment (MWS, SCS), as well as industrial point sources (INS), have been calculated separately in the mass-balance method. While in the modelling approach, all three sources have been aggregated into one scenario 
(A1). The difference between these sources in both methods is approx. $56 \%$, with the loads much higher for the massbalance method, especially for TN from the diffuse sources (SCS) due to the different retention percentage calculated for each nutrient using the mass-balance method.

In terms of diffuse sources reflecting different types of land use in the studied catchment, the urban areas (URB) have not been included in the mass-balance method due to the lack of suitable data. Whereas in the modelling method, this source accounted for $2.4 \%$ and $4.9 \%$ of the total TN and TP loads (A2), respectively. As for the agricultural activity (AGS) in the Wełna catchment, both methods indicated this source of nutrients as a main pressure in this area. Despite the substantial difference in TN load between both mass-balance and modelling approaches (approx. 767 ty $^{-1}$ ), the contribution of this source to the total load was consistent, reaching $82 \%$ for each method. As for TP, this contribution accounted for $61 \%$ and $54 \%$ for the mass-balance and the modelling method (A3), respectively. As for the forest areas (MFS) nutrient loads were considerably higher by approx. $40.1 \mathrm{ty}^{-1}$ and $0.7 \mathrm{ty}^{-1}$ for TN and TP, respectively, in the modelling approach (A4).

The natural background (NBS) and atmospheric deposition (ATS) nutrient pressures were calculated separately in the massbalance method, while the adopted modelling approach required their aggregation into one scenario (A5). The comparison of these loads between both methods revealed higher loads of TN by approx. $35.9 \mathrm{ty}^{-1}$ for the mass-balance scenario, while higher load of TP by approx. $5.3 \mathrm{ty}^{-1}$ was observed for the modelling method. As for the other sources (UKS), resulting from the differences observed in the mass-balance method between the river load and inventoried emissions, their contribution accounted for $2.4 \%$ of the TN total catchment load. In the modelling method, however, this source has been omitted since the presented list of scenarios already included all types of source data originally used to build the SWAT model for the Wełna River.

Table 1

Nutrient loads and source contributions for the mass-balance and modelling sources methods at the calculation profile of Oborniki (2017)

\begin{tabular}{|c|c|c|c|c|c|c|c|c|c|c|}
\hline \multirow[t]{2}{*}{ Source: } & & \multicolumn{4}{|c|}{ Mass-Balance method } & \multicolumn{5}{|c|}{ Modelling method } \\
\hline & & $\begin{array}{l}\text { TN load } \\
{\left[\mathrm{kgy}^{-1}\right]}\end{array}$ & $\%$ & $\begin{array}{l}\text { TP load } \\
{\left[\mathrm{kgy}^{-1}\right]}\end{array}$ & $\%$ & Scenario & $\begin{array}{l}\text { TN load } \\
{\left[\mathrm{kgy}^{-1}\right]}\end{array}$ & $\%$ & $\begin{array}{l}\text { TP } \\
\text { load } \\
\left.\text { [kgy }^{-1}\right]\end{array}$ & $\%$ \\
\hline $\begin{array}{l}\text { municipal point } \\
\text { sources }\end{array}$ & MWS & 132827 & 4.25 & 21530 & 34.17 & \multirow[t]{3}{*}{$\mathrm{A} 1$} & \multirow[t]{3}{*}{192898} & \multirow[t]{3}{*}{8.8} & \multirow[t]{3}{*}{$\begin{array}{l}13 \\
411\end{array}$} & \multirow[t]{3}{*}{25,9} \\
\hline $\begin{array}{l}\text { municipal diffuse } \\
\text { sources }\end{array}$ & SCS & 234829 & 7.51 & 496 & 0.79 & & & & & \\
\hline $\begin{array}{l}\text { industrial point } \\
\text { sources }\end{array}$ & INS & 1045 & 0.03 & 69 & 0.11 & & & & & \\
\hline urban & URB & - & - & - & - & $\mathrm{A} 2$ & 54107 & 2.4 & 2428 & 4,8 \\
\hline agriculture & AGS & $\begin{array}{l}2474 \\
435\end{array}$ & 79.11 & 32048 & 50.86 & A3 & $\begin{array}{l}1795 \\
696\end{array}$ & 82.2 & $\begin{array}{l}28 \\
120\end{array}$ & 54,4 \\
\hline forestry & MFS & 13800 & 0.44 & 23 & 0.04 & A4 & 53871 & 2.5 & 844 & 1,6 \\
\hline $\begin{array}{l}\text { natural } \\
\text { background }\end{array}$ & NBS & 57522 & 1.84 & 7670 & 12.17 & \multirow[t]{2}{*}{ A5 } & \multirow[t]{2}{*}{88595} & \multirow[t]{2}{*}{4.1} & \multirow[t]{2}{*}{6899} & \multirow[t]{2}{*}{13,3} \\
\hline $\begin{array}{l}\text { atmospheric } \\
\text { deposition }\end{array}$ & ATS & 71644 & 2.29 & 1178 & 1.87 & & & & & \\
\hline other sources & UKS & 141815 & 4.53 & 0 & 0.00 & - & - & - & - & - \\
\hline SEM & & $\begin{array}{l}3127 \\
916\end{array}$ & 100 & 63013 & 100 & $\mathrm{AO}$ & $\begin{array}{l}2185 \\
167\end{array}$ & 100 & $\begin{array}{l}51 \\
701\end{array}$ & 100 \\
\hline
\end{tabular}




\section{Discussion}

The comparison between the mass-balance method based solely on load-oriented approach and results obtained from the Makromodel DNS/SWAT for the medium-sized catchment, which has been presented in this study, has demonstrated discrepancies in the total nutrient loads and in the contribution of individual sources.

The river flow measurements and their translation into the model can be identified as the first source of these discrepancies. For the purposes of this study, the flow rate monitoring data (2017) has been taken from the Kowanówko gauge station (IMGW-PIB), where the water level is measured continuously (Fig. 4). The flow data from the very same profile, and from two others (Pruśce and Ryczywół) has also been used to calibrate, verify and validate the Wełna River model for the period of 2001-2018, which covers the entire flow cycle (low, medium and high river flows). Despite the very good or good model performance with regard to river flow monitoring data (Supplementary Table S2 and S3), generally an underestimation of the peak flows could be observed (Fig. 4). This phenomenon has been reported quite frequently ${ }^{[43][44]}$ and related to the curve number method used in the model adopted to estimate direct runoffs from rainfall events ${ }^{[45][46]}$.

To calculate total loads in the mass-balance method (eq. 1) TN and TP concentrations obtained from the SEM at the Oborniki monitoring station (2017), localised approx. 5 km downstream from the gauge station (Kowanówko), have been used. This difference has been neglected since no other tributary discharges into the main river at this distance. Since the quality monitoring in 2017 in Oborniki was performed with a monthly frequency, the linear interpolation method (eq. 2) was used to obtain the daily concentration values (Fig. 5). To confront these values with nutrient concentrations from the modelling approach, the TN and TP values were calculated from the simulated loads. This comparison (Fig. 5). clearly shows that daily variability of nutrient concentrations is high and not considered in the mass-balance method. The uncertainty of measurements performed under the SEM system were estimated at $19 \%$ and $16 \%$ for TN and TP concentrations, respectively. Taking into consideration that the uncertainty of flow measurements has been estimated at $5 \%$, the total uncertainty for mass-balance loads could be estimated (based on the root mean square error propagation method) at $19.6 \%$ and $16.7 \%$ for TN and TP loads, respectively. Whereas the uncertainty of nutrient loads in the modelling approach has been estimated at $12.5 \%$ and $20 \%$ for TN and TP loads, respectively.

The distribution of total TN and TP loads among the particular sources (Table 1) depicts anthropogenic activity related to municipal and industrial wastewater production as the second highest source of nutrients. It contributes to 11.0 and $36.0 \%$ according to the mass-balance method (MWS, SCS, INS), and 8.8 and $25.9 \%$ according to the modelling approach (A1), for TN and TP respectively. Due to the mainly agricultural character of studied catchment, the contribution of industrial sources (INS) can be considered as marginal, while substantial nutrient loads are discharged from the wastewater treatment facilities (Fig. 6). In both approaches, the discharges from different size WWTPs are regarded as point sources, releasing wastewater directly into the river bed phase. However, unlike in the mass-balance method, the modelling approach takes into account a number of processes, such as transport, biodegradation, transformation, dilution, diffusion, deposition and accumulation, taking place in this phase ${ }^{[29]}$, therefore modelled nutrient loads at the discussed profile can be expected to be much lower. The relatively low level of urbanization in the analysed catchment, and hence the sparsity of households,

impacts wastewater management in this area, which is still largely based on septic tanks ${ }^{[4][48]}$. The key factor for the calculation of the contribution of this source (SCS) to the total loads in both methods, is related to nutrient retention in the land phase. Significant differences between the adopted retention estimation methods lead to considerable differences between TN and TP load values. In the case of the mass-balance method, retention is calculated separately for nitrogen and phosphorus and based on the comparison between river loads and the sum of inventoried emissions in the catchment (source-oriented approach). Since in the studied catchment the nitrogen river load exceeded inventoried emissions, zero retention was assumed for this nutrient. As for phosphorus, the river load was much smaller than the inventoried emissions, therefore $99 \%$ of the retention was adopted and attributed solely to the diffuse sources, according to methodology described 
in 2.3.3. In the case of the modelling method, the retention of TN and TP resulting from anaerobic processes in septic tanks and transport of nutrients between land and river bed phases was included in the group of point sources.

In the case of sources where nutrient loads depend on the form of land use, the mass-balance method relied on an assessment based on outflow relative to the respective area of the catchment and TN and TP concentrations, measured or adopted for the particular land use form. In the modelling method, nutrient loads for these sources have been simulated based on land features embedded in the HRU system (slopes, soil type, land use) and combined with the meteorological and hydrological data. Eventually, the SWAT module simulates five different forms of nitrogen and six different forms of phosphorus, taking into account different pathways of nutrients delivery into the catchment and their removal through e.g. uptake by plants, volatilization, erosion, surface runoff, etc. The differences between the values of nutrient loads for diffuse sources in both methods have been shown in Table 1 and Fig. 6. In the case of urban areas (URB), which account for approx. $0.5 \%$ of the Wełna catchment, this form of land use has been omitted in the mass-balance method, due to the lack of pertinent data on nutrient concentrations. In the modelling approach (A2), three categories of urban areas depending on the intensity of development (continuous, discontinuous, industrial) characterized by the different share of impervious surfaces have been taken into consideration. The resulting nutrient loads were relatively low, however the noticeably higher value for TP should be highlighted. Many published records indicate that indeed runoff from urban areas is rich in phosphorus compounds ${ }^{[49][50][51][52]}$ due to industrial activities, dust particles from roads and construction sites, burning of fossil fuels, fertilizers and biogenic particles from green areas.

Since approx. $75 \%$ of the total Wełna catchment area represents agricultural land use (AGS), this source plays the dominant role in both methods, contributing to approx. 82 and $54-61 \%$ of the TN and TP loads, respectively. Although relative contributions in both methods are at a similar level, the absolute loads are lower in the modelling method (A3) by $30 \%$ for both nutrients. To adapt the mass-balance method to the Wetna catchment conditions, the measured nitrate and phosphate concentrations in shallow groundwater in this area and specific coefficients have been used (section 2.3.2). As for nutrient retention, zero nitrogen retention and $99 \%$ phosphorus retention has been implemented, as for other diffuse sources. The Macromodel DNS/SWAT, in turn, is a tool with a very extensive agricultural module ${ }^{[29][35]}$ and takes into account numerous data related to each type of the crop and agricultural practices (e.g., agrotechnical treatments, fertilization, crop rotation), therefore its results should be considered as more detailed.

The remaining $20 \%$ of the land use covered by forestry (MFS) delivered a minimal contribution to TN and TP loads according to the mass-balance method, which seems to be an artefact of the adopted low concentrations representing this type of land use. However, the high ability of forest soils to retain nutrients through different biotic and abiotic mechanisms is also a well-known phenomenon ${ }^{[53][54]}$. The estimated loads (A4) according to the modelling approach were noticeably higher, although still represented the lowest contribution to the nutrient content in relation to their surface area. Nutrient loads from the two remaining sources, natural background (NBS) and atmospheric deposition (ATS), were discharged both into the land and into the river bed phases. Although estimations according to both methods were based on a similar concept, the differences reached $30 \%$ and $80 \%$ for TN and TP, respectively. In the case of NBS, an attempt was made to recreate nutrient concentrations from the pre-human period, using coefficients on the natural background in undisturbed catchments ${ }^{[12]}$ according to the mass-balance method, and creating a variant scenario in a modelling approach where the entire catchment area was covered by forestry without any human activities ${ }^{[55][42]}$. As for ATS, which was combined in a single scenario along with NBS in the modelling simulations (A5), the data on pollutant atmospheric deposition was taken into consideration. However, phosphorus has not been included in the modelling method due to the limitations of the SWAT module, although both dry and wet deposition is minimal in Poland and does not exceed $0.34 \mathrm{kgPha}^{-1} \mathrm{y}^{-1}$ (Supplementary Table S1).

\section{Conclusion}


Two different approaches, source and load oriented, were used in parallel to balance nutrients in the middle-size agricultural catchment. This comparison has demonstrated similar contributions for each nutrient source and disparities in absolute TN and TP loads. Both methods require a significant amount of monitoring data, which are characterized by poor spatial correlation, high uncertainty and frequent discontinuities that affect the final estimations. However, in the case of the modelling approach, better representation of conditions and processes in the catchment area can compensate for a limited number of monitoring profiles. Although the tendency of the model to over- or underestimation of the results should not be overlooked, even if the model has been positively calibrated, verified, and validated. As for the mass balance method, although it can be considered simpler and easier to use, the omission of such processes as self-purification or illegal emissions overestimates the final load assessments. Upon the analysis of both methods in the context of their use by public administration, the best solution seems to be a hybrid approach currently used in some countries. The combination of the mass-balance and modelling methods enables their mutual verification and better adjustment to the local needs. It also enables the capture of potential changes resulting from e.g., climate or land use changes.

\section{Declarations}

\section{Acknowledgements}

For the purposes of this study, the authors have used the Wełna River catchment SWAT model, commissioned by the State Water Holding - Polish Waters (SWH-PW) under the project "Identification of pressures in water regions and river basin districts. Part III: Development of a model for calculating pollution loads" ${ }^{\text {[1] }}$. The research was partly supported by the program "Excellence initiative - research university" for the AGH University of Science and Technology.

\section{References}

1. SWH-PW - State Water Holding - Polish Waters. 2020b. Identification of pressures in water regions and river basin districts. Part III: Development of a model for calculating pollution loads (in Polish, English summary). https://www.apgw.gov.pl/pl/III-cykl-prace-realizowane-w-cyklu. Accessed 20 July 2020

2. Le Moal, M. et. al. 2019. Eutrophication: a new wine in an old bottle?. Science of the Total Environment 651, 1-11. https://doi.org/10.1016/j.scitotenv.2018.09.139

3. Zhang, X. et. al. 2020. Quantifying nutrient budgets for sustainable nutrient management. Global Biogeochemical Cycles 34(3) https://doi.org/10.1029/2018GB006060

4. Alam, M. J., Dutta, D. 2021. Modelling of Nutrient Pollution Dynamics in River Basins: A Review with a Perspective of a Distributed Modelling Approach. Geosciences 11(9), 369. https://doi.org/10.3390/geosciences11090369

5. European Union. 2020. Agriculture, forestry and fishery statistics. https://ec.europa.eu/eurostat/web/productsstatistical-books/-/ks-fk-20-001 doi: 10.2785/143455. Accessed 30 November 2021

6. HELCOM. 2019. HELCOM Guidelines for the annual and periodical compilation and reporting of waterborne pollution inputs to the Baltic Sea (PLC-Water). https://helcom.fi/wp-content/uploads/2019/08/PLC-Water-Guidelines-2019.pdf. Accessed 5 August 2021

7. HELCOM. 2021. Applied methodology for the PLC-7 assessment. https://helcom.fi/media/publications/Appliedmethodology-for-the-PLC-7-assessment-211202.pdf. Accessed 6 December 2021

8. Huttunen, I. et. al. 2016. A national-scale nutrient loading model for Finnish watersheds-VEMALA. Environmental Modeling \& Assessment 21(1), 83-109. https://doi.org/10.1007/s10666-015-9470-6

9. Mockler, E. M., Deakin, J., Archbold, M., Gill, L., Daly, D., Bruen, M. 2017. Sources of nitrogen and phosphorus emissions to Irish rivers and coastal waters: Estimates from a nutrient load apportionment framework. Science of the Total Environment 601, 326-339. https://doi.org/10.1016/j.scitotenv.2017.05.186

Page $11 / 18$ 
10. Malagó, A., Bouraoui, F., Grizzetti, B., De Roo, A. 2019. Modelling nutrient fluxes into the Mediterranean Sea. Journal of Hydrology: Regional Studies 22, 100592. https://doi.org/10.1016/j.ejrh.2019.01.004

11. Audet, J., Zak, D., Bidstrup, J., Hoffmann, C. C. 2020. Nitrogen and phosphorus retention in Danish restored wetlands. Ambio 49(1), 324-336. https://doi.org/10.1007/s13280-019-01181-2

12. SWH-PW - State Water Holding - Polish Waters. 2020a. Development of the balance of pollution loads discharged by rivers into the Baltic Sea - PLC7. (in Polish).

13. National Water Management Authority. 2017. Update of Map of the hydrographic division of Poland in the scale 1: 10 000. MPHP10. https://wody.isok.gov.pl/imap_kzgw/. (in Polish). Accessed: 5 August 2021

14. IMGW-PIB - Institute of Meteorology and Water Management - National Research Institute. 2021. Public data. https://danepubliczne.imgw.pl/. Accessed 2 April 2021

15. SWH-PW - State Water Holding - Polish Waters. 2019. Identification of pressures in water regions and river basin districts. Part II: Development of database of anthropogenic pressures. (in Polish). https://www.apgw.gov.pl/pl/III-cyklprace-realizowane-w-cyklu. Accessed 20 July 2020

16. Statistics Poland. 2021. Local Data Bank. https://bdl.stat.gov.pl/BDL/start. Accessed 1 December 2020

17. Chief Inspectorate of Environmental Protection. 2020. Synthetic report on the classification and assessment of the state of surface water bodies for 2019, based on data from 2014-2019 (in Polish). https://www.gios.gov.pl/pl/stansrodowiska/monitoring-wod. Accessed 2 April 2021

18. European Environmental Agency. 2018. Copernicus Land Monitoring Service 2018. Corine Land Cover 2018. https://land.copernicus.eu. Accessed 1 December 2020

19. SWH-PW - State Water Holding - Polish Waters. 2018. Report on the implementation of the National Program of Municipal Sewage Treatment for 2017. (in Polish). https://www.wody.gov.pl/nasze-dzialania/krajowy-programoczyszczania-sciekow-komunalnych. Accessed 5 August 2021

20. Pastuszak, M., Kowalkowski, T., Kopiński, J., Stalenga, J., Panasiuk, D. 2014. Impact of forecasted changes in Polish economy (2015 and 2020) on nutrient emission into the river basins. Science of the Total Environment 493, 32-43. https://doi.org/10.1016/j.scitotenv.2014.05.124

21. Chief Inspectorate of Environmental Protection. 2019. Precipitation chemistry. Chemizm opadów - stężenia i ładunki GIOŚ (gios.gov.pl). Accessed 2 April 2021

22. Wilk, P., Orlińska-Woźniak, P., Gębala, J., Ostojski, M. 2017. The flattening phenomenon in a seasonal variability analysis of the total nitrogen loads in river waters. Technical Transactions (11), 137-159.

23. Wilk, P., Orlińska-Woźniak, P., Gębala, J. 2018a. The river absorption capacity determination as a tool to evaluate state of surface water. Hydrology and Earth System Sciences 22(2), 1033-1050. https://doi.org/10.5194/hess-22-1033-2018

24. Wilk, P., Orlińska-Woźniak, P., Gębala, J. 2018b. Mathematical description of a river absorption capacity on the example of the middle Warta catchment. Environment Protection Engineering 44(4), 99-116. https://doi.org/10.5277/epe180407

25. Szalińska, E., Wilk, P. 2018. Sediment quantity management in polish catchment-riversea systems-should we care? Economics and Environment 3(66), 25-37.

26. Orlińska-Woźniak, P., Szalińska, E.,Wilk, P. 2020a. Do land use changes balance out sediment yields under climate change predictions on the Sub-Basin scale? The Carpathian Basin as an example. Water 12(5), 1499.

https://doi.org/10.3390/w12051499

27. Orlińska-Woźniak, P., Wilk, P., Szalińska, E. 2020b. Delimitation of nutrient vulnerable zones-a comprehensive method to manage a persistent problem of agriculture. Agricultural Systems 83: 102858.

https://doi.org/10.1016/j.agsy.2020.102858

28. Pignotti, G., Rathjens, H., Cibin, R., Chaubey, I., Crawford, M. 2017. Comparative analysis of HRU and grid-based SWAT models. Water 9(4), 272. https://doi.org/10.3390/w9040272

Page $12 / 18$ 
29. Arnold, J. G., Moriasi, D. N., Gassman, P. W., Abbaspour, K. C., White, M. J. 2012. SWAT: Model use, calibration, and validation. Transactions of the ASABE. 55(4), 1491-1508. https://doi.org/10.13031/2013.42256

30. Sullivan, T. P., Gao, Y. 2016. Assessment of nitrogen inputs and yields in the Cibolo and Dry Comal Creek watersheds using the SWAT model, Texas, USA 1996-2010. Environmental Earth Sciences 75(9), 725. https://doi.org/10.1007/s12665-016-5546-0

31. Epelde, A. M. et. al. 2016. Different modelling approaches to evaluate nitrogen transport and turnover at the watershed scale. Journal of Hydrology 539, 478-494. https://doi.org/10.1016/j.jhydrol.2016.05.066

32. Ikenberry, C. D. et. al. 2017. Simulation of daily flow pathways, tile-drain nitrate concentrations, and soil-nitrogen dynamics using SWAT. Journal of the American Water Resources Association 53(6), 1251-1266.

https://doi.org/10.1111/1752-1688.12569

33. Jian, C. et. al. 2021. Evaluating the influence of hydrological conditions on the phosphorus loads in an agricultural river basin using the SWAT model. Hydrology Research. https://doi.org/10.2166/nh.2021.165

34. Neitsch, S. L., Arnold, J. G., Kiniry, J. R., Williams, J. R. 2011. Soil and water assessment tool theoretical documentation version 2009. Texas Water Resources Institute. from https://scholar.google.pl/scholar?

q=Soil+and+water+assessment+tool+theoretical+documentation+version+2009\&hl=pl\&as_sdt=0\&as_vis=1\&oi=scholart

35. Arnold, J. G. et. al. 2013. SWAT 2012 input/output documentation. Texas Water Resources Institute. from https://hdl.handle.net/1969.1/149194

36. Piniewski, M., et. al. 2021. How effective are River Basin Management Plans in reaching the nutrient load reduction targets? Ambio 50(3), 706-722. https://doi.org/10.1007/s13280-020-01393-x

37. Hosseini, S. H., Khaleghi, M. R. 2020. Application of SWAT model and SWAT-CUP software in simulation and analysis of sediment uncertainty in arid and semi-arid watersheds (case study: The Zoshk-Abardeh watershed). Modeling Earth Systems and Environment 6(4), 2003-2013. https://doi.org/10.1007/s40808-020-00846-2

38. Zhang, D. 2017. A coefficient of determination for generalized linear models. The American Statistician 71(4), 310-316. https://doi.org/10.1080/00031305.2016.1256839

39. Goshime, D. W., Absi, R., Ledésert, B. 2019. Evaluation and bias correction of CHIRP rainfall estimate for rainfall-runoff simulation over Lake Ziway watershed, Ethiopia. Hydrology 6(3): 68. https://doi.org/10.3390/hydrology6030068

40. Pool, S., Vis, M., Seibert, J. 2018. Evaluating model performance: towards a non-parametric variant of the Kling-Gupta efficiency. Hydrological Sciences Journal 63(13-14), 1941-1953. https://doi.org/10.1080/02626667.2018.1552002

41. Orlińska-Woźniak, P., Szalińska, E., Jakusik E., Bojanowski, D., Wilk, P. 2021. Biomass Production Potential in a River under Climate Change Scenarios. Environmental Science and Technology 55(16), 11113-11124 https://doi.org/10.1021/acs.est.1c03211

42. Wilk, P., Orlińska-Woźniak, P. 2019. Use of the macromodel DNS/SWAT to calculate the natural background of TN and TP in surface waters for the RAC parameter. Architecture Civil Engineering Environment 12(1). https://doi.org/10.21307/ACEE-2019-017

43. Kim, N. W., Lee, J. W., Lee, J., Lee, J. E. 2010. SWAT application to estimate design runoff curve number for South Korean conditions. Hydrological processes 24(15), 2156-2170. https://doi.org/10.1002/hyp.7638

44. Zhang, D., Lin, Q., Chen, X., Chai, T. 2019. Improved curve number estimation in SWAT by reflecting the effect of rainfall intensity on runoff generation. Water 11(1), 163. https://doi.org/10.3390/w11010163

45. Kannan, N., White, S. M., Worrall, F., Whelan, M. J. 2007. Hydrological modelling of a small catchment using SWAT2000-Ensuring correct flow partitioning for contaminant modelling. Journal of Hydrology 334(1-2), 64-72. https://doi.org/10.1016/j.jhydrol.2006.09.030

46. Shrestha, M. K., Recknagel, F., Frizenschaf, J., Meyer, W. 2016. Assessing SWAT models based on single and multi-site calibration for the simulation of flow and nutrient loads in the semi-arid Onkaparinga catchment in South Australia. Agricultural Water Management 175, 61-71. https://doi.org/10.1016/j.agwat.2016.02.009

Page $13 / 18$ 
47. Zbierska, A., Oliskiewicz-Krzywicka, A. 2017. Condition of municipal wastewater management in Wielkopolska in the years 1999-2015. Ecological Engineering \& Environmental Technology 18(5), 27-35.

https://doi.org/10.12912/23920629/76231

48. Piasecki, A. 2019. Water and sewage management issues in rural Poland. Water 11(3), 625. https://doi.org/10.3390/w11030625

49. Toor, G. S. et. al. 2017. Managing urban runoff in residential neighborhoods: Nitrogen and phosphorus in lawn irrigation driven runoff. PLOS ONE 12(6). https://doi.org/10.1371/journal.pone.0179151

50. Decina, S. M., Templer, P. H., Hutyra, L. R. 2018. Atmospheric inputs of nitrogen, carbon, and phosphorus across an urban area: Unaccounted fluxes and canopy influences. Earth's Future 6(2), 134-148.

https://doi.org/10.1002/2017EF000653

51. Luo, H., et. al. 2020. Influence of filter layer positions and hydraulic retention time on removal of nitrogen and phosphorus by porous asphalt pavement. Water Science and Technology 81(3), 445-455.

https://doi.org/10.2166/wst.2020.110

52. Yang, YY., Toor, G.S. Stormwater runoff driven phosphorus transport in an urban residential catchment: Implications for protecting water quality in urban watersheds. Sci Rep 8, 11681 (2018). https://doi.org/10.1038/s41598-018-29857-x

53. Zhu, X., Zhang, W., Chen, H., Mo, J. 2015. Impacts of nitrogen deposition on soil nitrogen cycle in forest ecosystems: A review. Acta Ecologica Sinica 35(3), 35-43. https://doi.org/10.1016/j.chnaes.2015.04.004

54. Bechtold, H. A., Rosi, E. J., Warren, D. R., Keeton, W. S. 2017. Forest age influences in-stream ecosystem processes in Northeastern US. Ecosystems 20(5), 1058-1071. https://doi.org/10.1007/s10021-016-0093-9

55. Yen, H. et. al. 2016. Western Lake Erie Basin: Soft-data-constrained, NHDPlus resolution watershed modeling and exploration of applicable conservation scenarios. Science of the Total Environment 569, 1265-1281.

https://doi.org/10.1016/j.scitotenv.2016.06.202

\section{Figures}




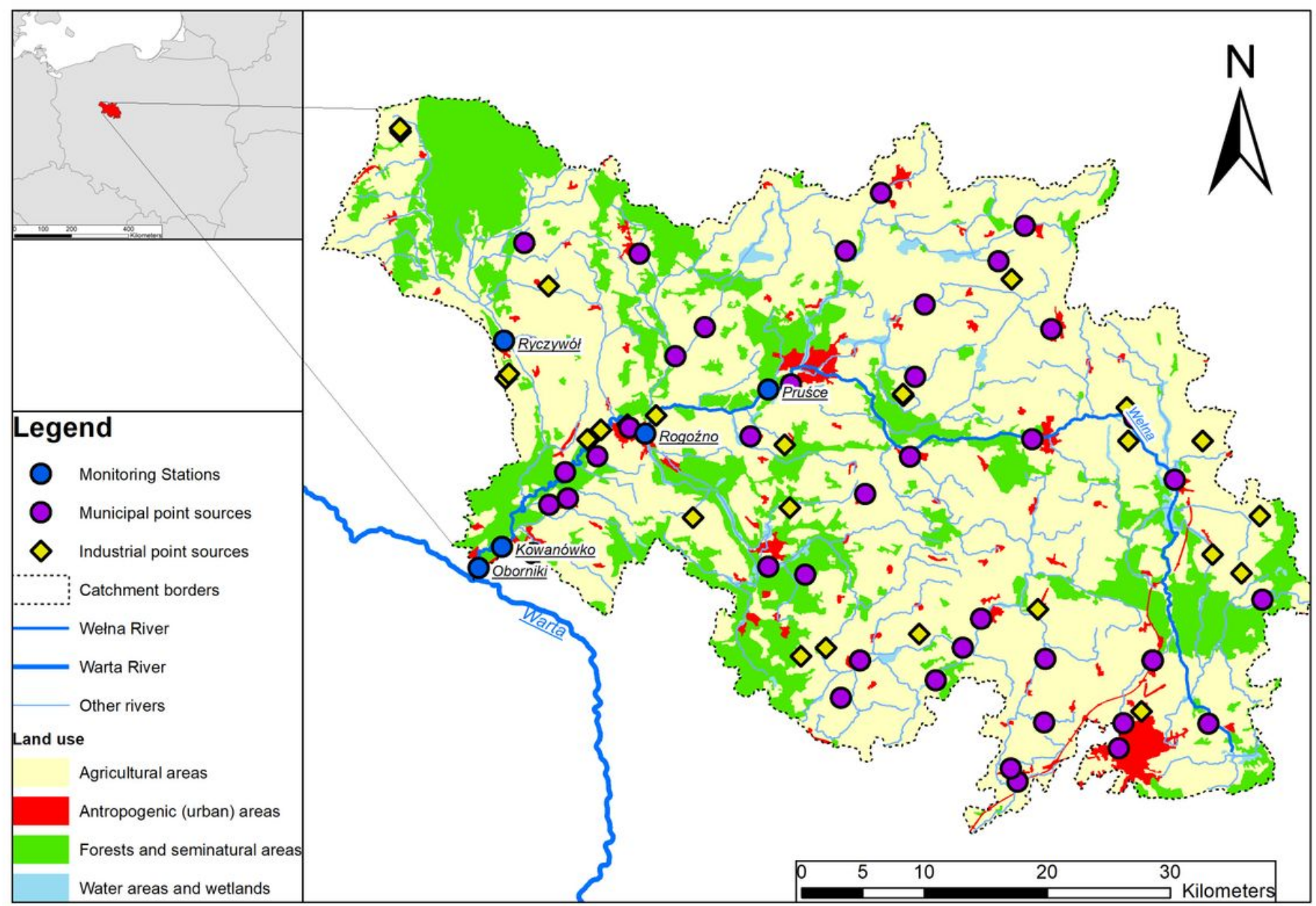

Figure 1

Localisation of the Wełna River catchment with its land use forms and nutrient sources 


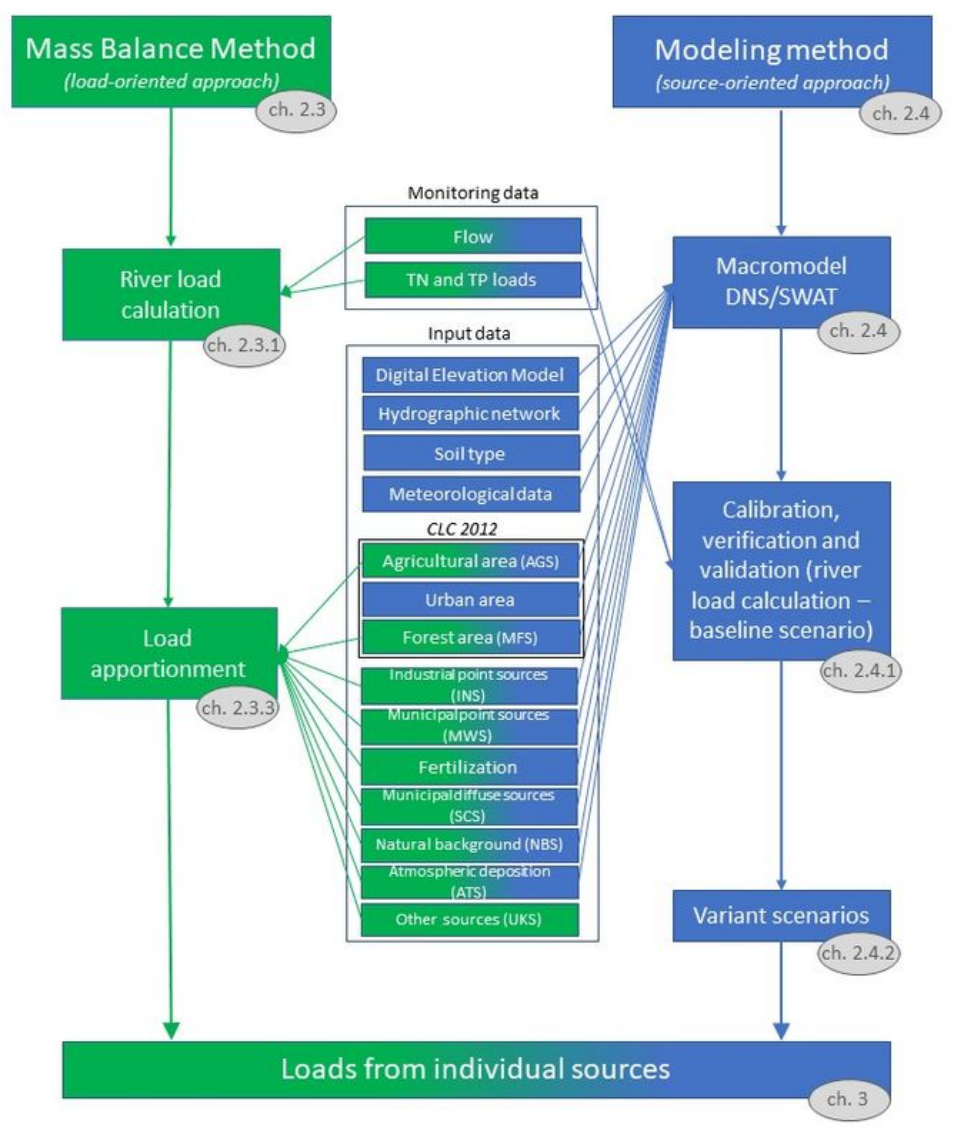

Figure 2

Methodology diagram (relevant chapters marked in grey ovals) 


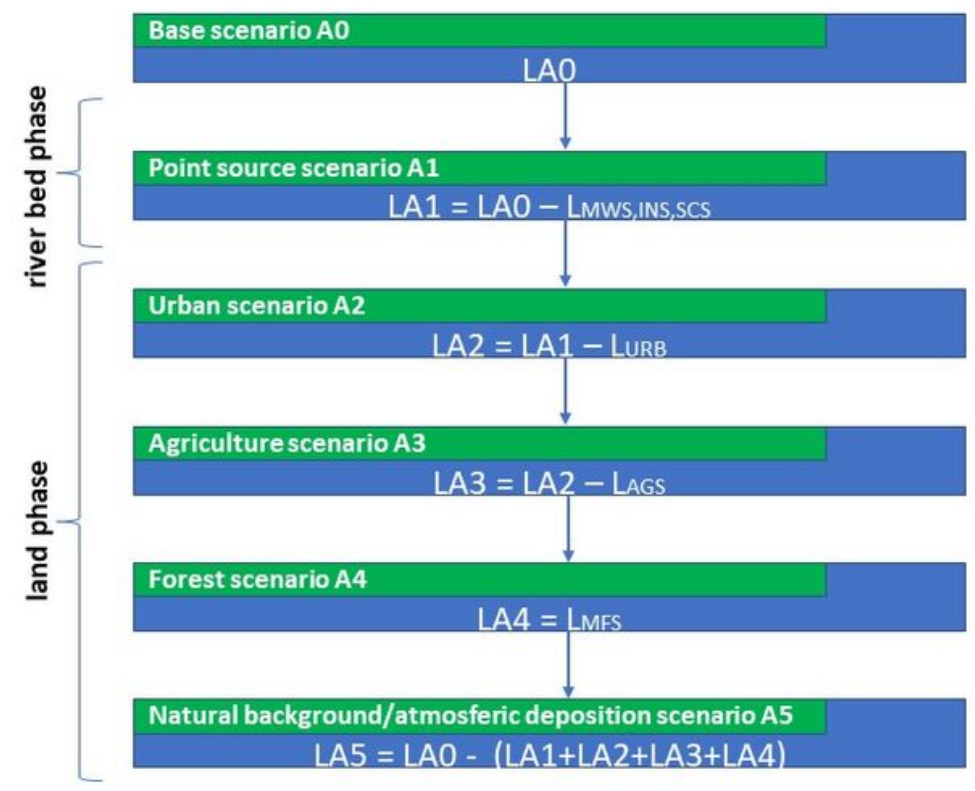

Figure 3

Diagram of the process of analysis of variant scenarios imitating changes in land use in the land phase of the catchment
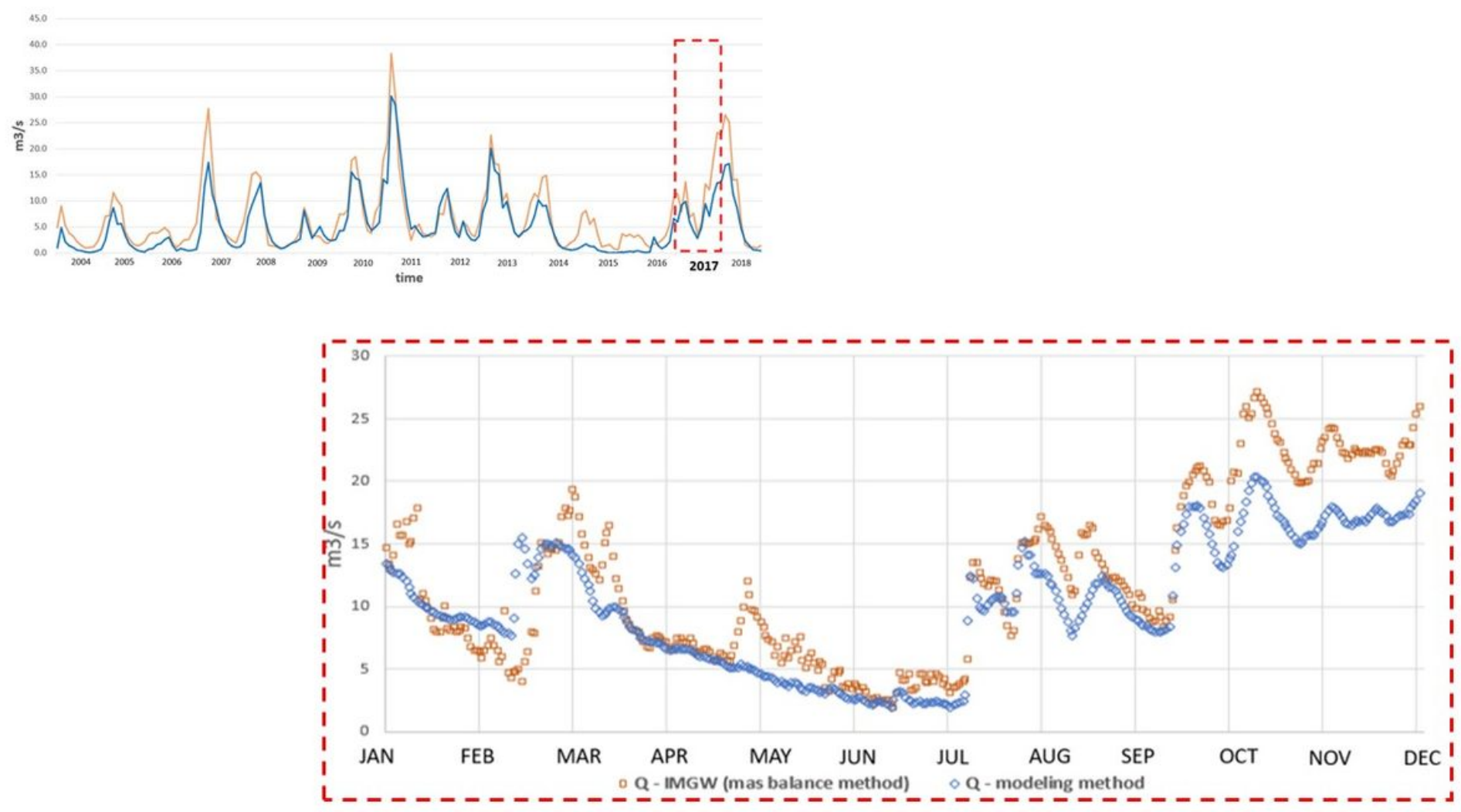

Figure 4 


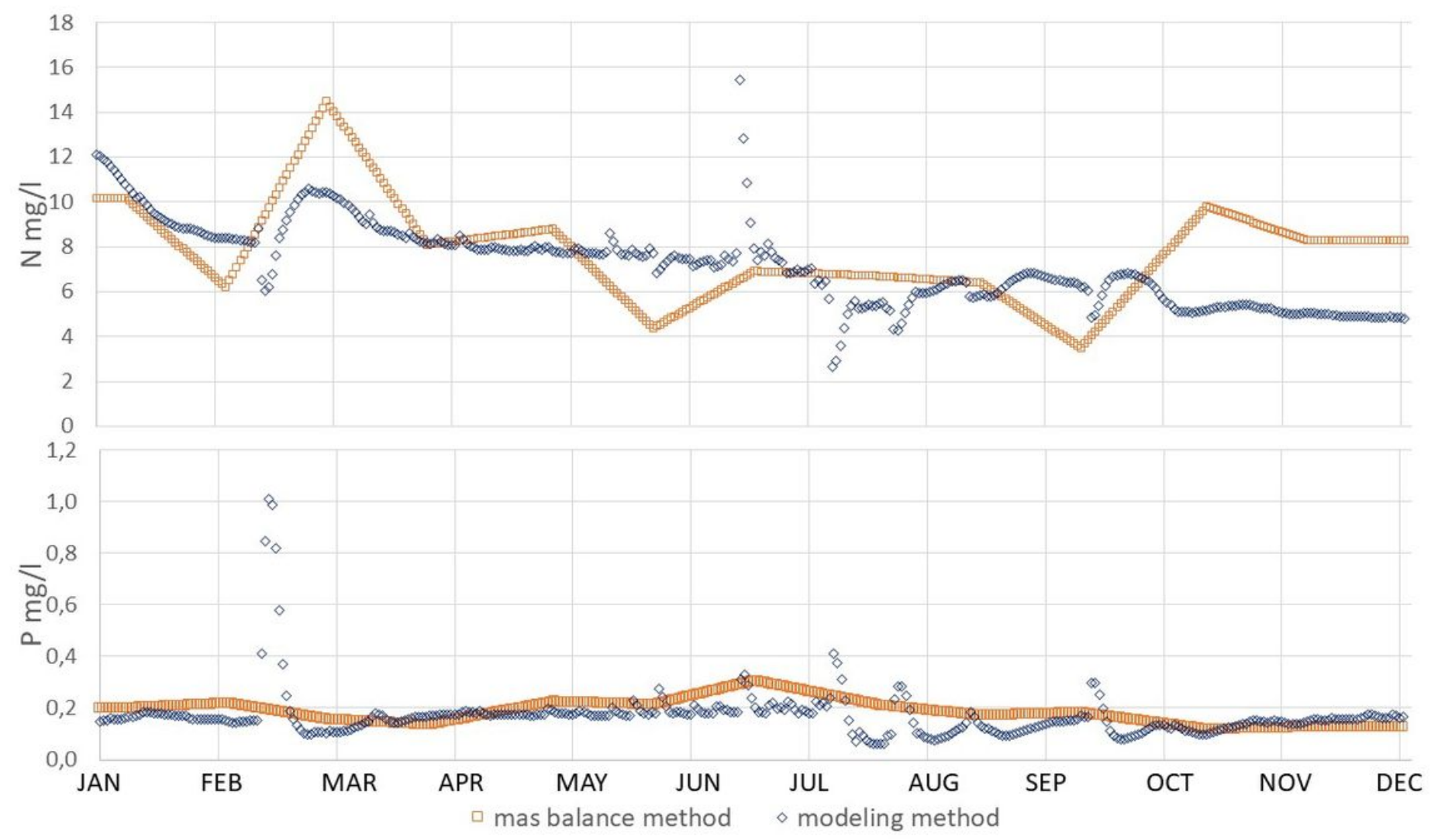

\section{Figure 5}

Comparison of simulation results and interpolated monitoring data for nitrogen and phosphorus concentrations for the Wełna River (Oborniki profile, 2017)

\section{Figure 6}

Distribution of TN and TP loads in the Wetna River according to the mass-balance and modelling approaches (delineation of sources based on the boundaries of land-use types)

\section{Supplementary Files}

This is a list of supplementary files associated with this preprint. Click to download.

- Supplementarymaterial.docx 